\title{
ПРАВОВЕ ВИХОВАННЯ УЧНІВСЬКОЇ МОЯОДІ В ЗАКЛАДАХ ПРОФЕСІЙНО-ТЕХНІЧНОЇ ОСВІТИ УКРАЇНИ (70-ТІ РР. ХХ СТ.)
}

У статті на основі аналізу джерельної бази досліджено, як було організовано правове виховання учнівської молоді в 70-ті роки ХХ сторіччя в закладах професійно-технічної освіти України.

Розглянуто різні форми правового виховання, використання яких спрямовували на вирішення педагогічними колективами закладів професійно-технічної освіти таких завдань правового виховання: формування правової свідомості; вироблення у вихованців умінь, навичок, звичок поведінки відповідно до правових норм; формування в них активної позиції у правовій сфері; подолання у правовій свідомості вихованців помилкових поглядів і переконань.

Акцентовано, щио в 70-ті роки ХХ сторіччя в закладах професійно-технічної освіти України з метою правового виховання молоді проводилися уроки з дисциплін «Питання радянського права» $i$ «Трудове право», а також створювалися університети правових знань, клуби вихідного дня, кабінети $і$ кутки радянського права, у позаурочний час на відповідну тематику організовувалися лекції, лекторії, усні журнали, вечори запитань $і$ відповідей, диспути, бесіди, місячники права, конференції, обговорювалися статті журналу "Дюдина ізакон», виготовлялися стінгазети, діяли загони «Юних дзержинців», суди честі, товариські суди, ради профілактики, перевиховання, здійснювалася просвітницька робота з батьками. Однак перевага надавалася просвітницькій роботі, у процесі якої, як правило, уся увага зосереджувалася на поясненні, переконанні, тобто на формуванні в учнівської молоді правової свідомості, тоді як інші завдання правового виховання часом залишалися поза належною увагою.

Підсумовано, що, попри вищезгадане, у 70-ті роки ХХ сторіччя в закладах професійнотехнічної освіти України до організациї правового виховання учнівської молоді підходили комплексно, а роботу з цзвого напряму виховання проводили циілеспрямовано та систематично.

Ключові слова: заклади професійно-технічної освіти, учнівська молодь, правове виховання, завдання правового виховання, форми правового виховання.

Постановка проблеми. В умовах кризи, коли в нашій країні знижується рівень життя, перестає нормально функціювати суспільство, спостерігаються певні порушення соціального та правового порядку, перед науковцями стоїть завдання пошуку нових підходів до виховання правової свідомості мододого покоління. Одним із шляхів вирішення цього завдання правового виховання є врахування вітчизняного історикопедагогічного досвіду. Він потребує детального вивчення, відокремлення позитивних і негативних аспектів задля імплементації перших у процес виховання в сучасних закладах освіти та уникнення можливих помилок.

Аналіз досліджень. Проблематика правового виховання знайшла широке відображення в наукових дослідженнях учених радянської доби та сучасного періоду. Зокрема, це праці таких науковців: Н. Головко, А. Долгова, А. Зюбин, А. Кожевнікова, А. Кузьмінский, А. Медведев, Г. Міньковский, В. Омедяненко, В. Саюшев, Г. Терещенко та ін. Проте вони переважно розгдядали правове виховання мододі в контексті загального виховного процесу.

Метою статті є дослідження організації правового виховання учнівської мододі в закладах професійно-технічної освіти України в 70-ті роки XX сторіччя.

*C Пислар А. Б.

U3 251 
Викдад основного матеріалу. Правове виховання, як зазначає Н. Головко навчальному посібнику «Правова педагогіка» (2007), зміцнюе життєву позицію, підвищує громадянську активність, загострює почуття непримиренності до негативних явищ. Його специфіка зумовлена соціально-правовим статусом учнівської молоді в суспільстві [1, с. 65].

А. Кузьмінський і В. Омелянко в підручнику «Педагогіка» (2008) акцентують, що метою правового виховання $є$ формування в усіх громадян високої правової культури, яка складається, передусім, зі свідомого ставдення до своїх прав і обов'язків, з глибокої поваги до законів і правил людського співжиття, готовності дотримуватися й сумлінно виконувати визначені вимоги, які виражають волю й інтереси народу [5, с. 280].

Учені виділяють такі провідні завдання правового виховання:

1) формування правової свідомості, яка є головним фактором, що визначає особливості поведінки особистості;

2) вироблення у вихованців умінь, навичок, звичок поведінки відповідно до правових норм;

3) формування у вихованців активної позиції у правовій сфері, що має виявлятися в непримиренному ставленні до правопорушень, прагненні боротися з цим явищами;

4) подолання у правовій свідомості вихованців помилкових погдядів і переконань, які сформувалися ще раніше в негативному середовищі народу [5, с. 280].

Ці завдання досить успішно реалізовувалися в процесі правового виховання учнівської молоді в радянську добу, коли державні органи значну (часом надмірну) увагу приділяли управлінню виховним процесом. Звісно, тоді домінуючу родь у всіх процесах відігравало керівництво радянської держави, яке й виробляло стратегію розвитку ідеологічної роботи, зокрема правового виховання молодого покоління. Зокрема, у 70-х роках XX сторіччя в закладах професійно-технічної освіти України правове виховання учнівської мододі спрямовувалося на виконання директив XXIV-XXV з'іздів КПРС, у яких були запропоновані заходи щодо поліпшення цього напряму виховної роботи.

Наприклад, у постанові КПРС і Ради Міністрів СРСР від 23 червня 1972 року «Про подальше вдосконалення системи професійно-технічної освіти» йдеться про посилення уваги до ідейно-політичного, морально-етичного, естетичного і фізичного виховання учнівської молоді, а також про розробку нових форм виховного процесу [4, с. 100].

Використання цих форм мало допомагати педагогічним колективам закладів професійно-технічної освіти України вирішувати всі вищезгадані завдання правового виховання.

Для вирішення 1-го завдання (формування правової свідомості, яка є головним фактором, що визначає особливості поведінки особистості) використовувалися різні форми організації навчання і виховання учнів.

Розглянемо форми правового виховання більш детально.

У 70-ті роки XX століття основною формою правового виховання були уроки 3 таких навчальних дисциплін: «Питання радянського права», «Трудове право». Відповідно до нормативно-правових документів вони водилися з 1972 року. За всіма темами, які вивчали учні, треба було писати реферати, твори, оформлювати альбоми, виступати 3 доповідями на морально-правову тематику. На ці уроки запрошували співробітників медвитверезників, медичних працівників, суддів, прокурорів. Щоб учні краще засвоювали певні теми, застосовували картки-завдання, що сприяло активізації уваги і міцності засвоєння навчального матеріалу. Для підвищення ефективності навчально-виховного процесу уроки 3 дисциплін «Питання радянського права», «Трудове право» проводилися в кабінетах, які спеціально забезпечувадися наочною агітацією i технічними засобами навчання (діапроєкторами, магнітофонами, телевізорами тощо) [8, арк. 1, 2]. 
Вивчення трудового права відбувалося й на уроках виробничого навчання, де учнів привчали до дисципліни, планування своєї праці, раціонального використання робочого часу, роботи в колективі, дотримання техніки безпеки. У них виховували відповідальність, формували вміння аналізувати свої помилки, тобто уроки виробничого навчання надавали учням мождивість на практиці вивчати трудове право, що значно покращувало засвоєння навчального матеріалу.

Важливе місце в правовому виховані учнівської молоді відводилося позаурочній роботі, зокрема лекціям на відповідні теми. 3 цією метою запрошували дікарів психдиспансерів та витверезників, представників правоохоронних органів, працівників юстиції, судів, прокурорів, майстрів виробничого навчання, учителів, вихователів, наставників з базових підприємств, ветеранів праці. На лекціях, як показує аналіз звітів із правового виховання за 1976 рік, порушували такі теми: «Питання радянського права»; «Алкоголь і особистість»; «Алкоголь, його шкода і боротьба суспільства». У закладах професійно-технічної освіти України працювади лекторії, де проводиди лекції, які були спрямовані на морально-правове виховання молоді [7, арк. 21, 42]

На правову тематику випускали так звані усні журнали («Закони Батьківщини моєї», «Закон і мораль» тощо). Вони складалися з 5-6 «сторінок», по 10 хвилин кожна це виступи різних спеціалістів, короткометражні фільми тощо [2, с. 142].

У цей час у закладах професійно-технічної освіти України проводидися конференції правових знань, правові університети, куди також запрошували лікарів, судів, прокурорів [7, арк. 40,60]. Випускали стінні газети, де наводили приклади позитивних вчинків радянських громадян [6, арк. 63; 8, арк. 29]. I доповнювала все це наочна агітація, яку розміщували у створених спеціадьно «Кутках радянського права» [7, арк. 2].

Зазначене підтверджують звіти 3 правового виховання в досліджуваний період. У них схарактеризовано такі форми роботи 3 учнівською мододдю: уроки «Питання радянського права», «Трудове право», університет правових знань, клуби вихідного дня, наочна пропаганда в «Кабінетах радянського права» $\mathrm{i}$ «Кутках радянського права», лекції, лекторії, усні журнали, вечори питань і відповідей, диспути, бесіди, місячники права, стінні газети на правову тематику, конференції правових знань, обговорення статей журналу «Дюдина і закон» [7, арк. 1, 2, 12, 15, 37, 38, 40, 42, 79; 8, арк. 28, 29].

Усі вищеперераховані форми допомагали вирішувати й друге завдання правового виховання - вироблення у вихованців умінь, навичок, звичок поведінки відповідно до правових норм.

На виконання третього завдання правового виховання (формування у вихованців активної позиції у правовій сфері, що має виявлятися в непримиренному ставленні до правопорушень, прагненні боротися 3 цими явищами) в закладах професійнотехнічної освіти спрямовувалися не лише різні форми правового, а й моральноестетичного виховання.

Оскільки в 70-ті роки XX сторіччя наголошувалося, що моральне і правове виховання невід'ємні, учені А. Додгова, А. Кожевнікова, А. Медведєв, Г. Міньковский та А. Зюбин пояснювали це тим, що по-перше, принципи і норми радянського права створюються з принципів і норм радянської моралі, грунтуються на них. По-друге, ніяке знання права не піднімае до рівня соціалістичної правосвідомості, якщо не забезпечений тісний зв'язок цього знання зі знанням норм радянської моралі, 3 переконаністю в істотності і непорушності морадьних норм, 3 потребою в їх використанні та дотриманні [3, с. 107].

3 цього приводу В. Саюшев у книзі «Организация и совершенство профессионально-технического образавания» (1987) написав, що морально-естетичне виховання формує активну життеву позицію, свідоме ставлення до громадського обов'язку, утверджує єдність слова і справи - щоденну норму поведінки і образу життя мододих робітників; виховуе такі якості: принциповість, чесність, нетерпимість

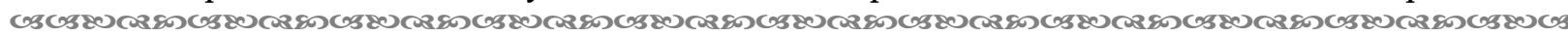
253 
до хуліганства, користодюбства, п’янства, байдужості до дюдини, прояву приватновласницьких тенденцій, бережливе ставлення до соціальної власності, до навколишнього середовища тощо [7, с. 140-141].

У 70-ті роки XX сторіччя основними формами морального виховання, які допомагали вирішувати трете завдання правового виховання, зазначене вище, були лекції («Два світи - дві моралі», «Про честь робітника», «XXV 3“їд про правове виховання молоді і подальше зміцнення соціалістичної законності», «Покінчити

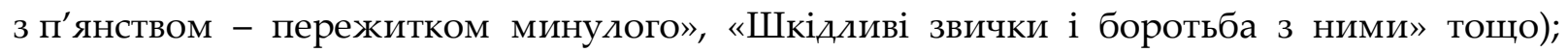
вечори-зустрічі 3 передовиками виробництва, суддями, прокурорами, дікарями («Закон, за яким щастя приходить», «Читай, заздри: я - громадянин Радянського Союзу», «Запитання та відповіді» тощо); бесіди («Закон потрібно знати» тощо); диспути («Про дівочу гордість», «Твій громадянський обов' язок» тощо) [3; 6; 7].

Головними недоліком майже всіх цих форм було те, що вони носиди просвітницький характер, тобто впливали, передусім, на формування правової свідомості учнів, а на вироблення в них умінь, навичок, звичок поведінки відповідно до правових норм здійснювали лише опосередкований вплив [3, с. 114].

Наприкінці 70-х років XX сторіччя в закладах професійно-технічної освіти України досить успішно діяли загони «Юних дзержинців», які допомагали учням ставати активними пропагандистами правових знань, норм права і борцями за суворим їх дотримуванням, позбавлятися від своїх недоліків у цій сфері [там само, с. 144]. У таких загонах створювалися належні умови для вирішення всіх завдань правового виховання.

Згідно з архівними даними, ці загони дозволяли отримати найкращі резудьтати в боротьбі з правопорушниками. Наприклад, унаслідок плідної роботи загону «Юних дзержинців», який було створено на базі Херсонського технічного училища № 3, учнями цього закладу за звітний період не було скоєно жодного кримінального здочину [8, арк. 43].

Діяльність подібних організацій унормовувалася «Типовими положеннями про загін юних дзержинців та про профільний загін юних друзів міліції», затвердженими постановою ЦКВЛКСМ, колегією Міністерства внутрішніх справ СРСР, колегією Державного комітету Ради Міністрів СРСР з професійно-технічної освіти від 18 квітня 1978 року № C-156(19)9 P-1.

У документі визначалось, що загін дзержинців (колектив учнів загальноосвітньої школи, професійно-технічного училища, середнього спеціального навчального закладу) організовується 3 метою вдосконалення морального виховання та підвищення правосвідомості дітей і учнів [2, с. 27].

Однак такою формою роботи було неможливо охопити всіх учнів, адже, поперше, існували певні обмеження щодо участі в цих загонах, а по-друге, панувала думка, що недисциплінований учень і правопорушник не може бути членом цього загону, бо він не виконуе вимог закону, не може навчати цьому інших і вимагати цього від інших [3, с. 144].

У 70-ті роки XX сторіччя четверте завдання правового виховання учнів (подолання у правовій свідомості вихованців помилкових поглядів і переконань, які сформувалися ще раніше в негативному середовищі народу) вирішували шияхом їхнього перевиховання.

При цьому основними формами роботи були суди честі; товариські суди; ради профілактики тощо. За правопорушниками закріплювали наставників, які проводили індивідуально виховну роботу. До процесу перевиховання активно долучадися дитячі кімнати для неповнолітніх, де також проводилася індивідуальна виховна робота. Правопорушення учнів висвітлювали на шпальтах «Сатиричної газети», «Фотогазети» тощо. 3 учнівською молоддю вели систематичну цілеспрямовану роботу в гуртожитках. До роботи залучали батьків правопорушників і загони «Юних дзержинців» [7, арк. 13, $15,36,43,65,69,86]$.

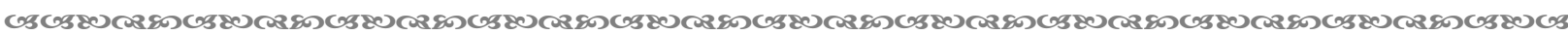
254 
У кожному закладі професійно-технічної освіти була своя специфіка роботи 3 правопорушниками, спрямована на подолання у правовій свідомості вихованців помилкових поглядів і переконань. Цим займалися не тільки суди честі, товариські суди, ради профілактики, а й ради майстрів. Останні на своїх засіданнях розглядали, зазвичай, такі питання: план роботи 3 важковиховуваними дітьми; причини неуспішності учнів; порушення учнями статутних вимог; виховання важковиховуваних учнів; факти аморальної поведінки тощо [8, арк. 35].

За кожним випадком ухвалювалися індивідуальні, виважені рішення. За правопорушником закріплювали наставника (майстра виробничого навчання, учителя, вихователя, ветерана праці, представника базового підприємства), який брав шефство над учнем, проводив індивідуальну роботу з ним. Це фіксувалося в журналі або в індивідуальних картках, які заводили на порушників. Крім того, справи правопорушників передавали в дитячі кімнати міліції, де з учнями індивідуально працювали інспектори [там само, арк. 13, 35, 37, 67, 69, 76]. Зазначене допомагало подолати у правовій свідомості вихованців помилкові погляди і переконання.

У 70-ті роки XX сторіччя специфіка правового виховання «важких» учнів полягала в його індивідуалізації, відборі таких форм роботи, які були найефективнішими в кожному окремому випадку. При цьому прагнули враховувати певні особливості, які впливають на правосвідомість та поведінку важковиховуваного учня: егоїстичні риси особистості, рівень правових знань, неповага до закону, небажання дотримуватися закону, нерішучість, слабка воля, імпульсивність [3, с. 143].

Як уже зазначалося, у закладах професійно-технічної освіти України до виховної роботи долучади батьків учнів, зокрема, з ними велася просвітницька робота щодо подолання проблем в правовому вихованні.

Просвітницьку роботу вели не тільки педагогічні колективи закладів професійнотехнічної освіти, а й працівники міліції. Для батьків проводилися лекції на правову тематику. Особлива увага приділялася батькам, діти яких були важковиховуваними. До них додому приходив інспектор 3 дитячої кімнати, проводив індивідуадьну роботу 3 батьками, перевіряв, у яких умовах виховується учень [9, арк. 56]. Це надавало мождивість більше дізнатися про певного учня та середовище, у якому він виховується, а за потреби - здійснювати вплив на це середовище. Така робота допомагала, наприклад, вирішити четверте завдання правового виховання (подолання у правовій свідомості вихованців помилкових поглядів і переконань).

Висновки. У 70-ті роки XX сторіччя до правового виховання учнів у закладах професійно-технічної освіти України застосовувався комплексний підхід. Роботу з цього напряму виховання проводили цілеспрямовано та систематично, добираючи найбільш дієві форми і уникаючи шаблонності.

Однак подекуди педагоги надмірно захоплювалися просвітницькою роботою, намагаючись переважно силою свого слова вплинути на учнівську молодь. Це не давало бажаного результату.

У цьому контексті нагадаємо думку Л. Зюбіна, який писав, що результат - знання, нехай безсистемні і несильно глибокі, але знання основних моральних норм все-таки є, а досвіду їх застосування немає, унаслідок чого виникали аморальні особистості, які потребували перевиховання [3, с. 144].

Разом із тим досвід правового виховання учнівської молоді, набутий у закладах професійно-технічної освіти України в 70-ті роки XX століття, попри його заідеологізованість і формалізм, заслуговуе на схвалення й подальше вивчення. Детального дослідження потребують методи й засоби правового виховання учнів, яким надавали перевагу у вищезгаданих закладах.

\section{Список використаних джерел:}

1. Головко Н. І. Правова педагогіка : навчальний посібник. К. : МАУП, 2007. 248 с.

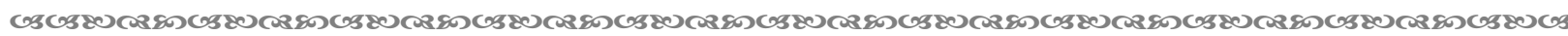
255 
2. Типові положення про загін юних дзержинців та про профільний загін юних друзів міліції. Збірник наказів та інструкцій Міністерства освіти Української РСР. 1978. № 18. С. 25-32.

3. Зюбин $\lambda$. М. Учебно-воспитательная работа с трудными учащимися. М. : Высшая школа, 1982. $191 \mathrm{c}$.

4. КПСС, Советское государство о подготовке мододой смены рабочего класса. 1940-1987 гг. / сост. Г. И. Терещенко. К. : Высшая школа, 1988. 416 с.

5. Кузьмінский А. І., Омеляненко В. А. Педагогіка : підручник. 3-те вид., випр. К. : Знання-Прес, 2008. 447 с.

6. Отчет об идейно-воспитательной, культурно-массовой и физкультурно-спортивной работы за 1976 г. Державний архів Херсонської області (ДАХО). Ф-Р 3598. Оп. З. Спр. 19. 84 арк.

7. Саюшев В. С. Организация и совершенствование профессионально-технического образования. М. : Высшая школа, 1987. 175 с.

8. Справки училищ о работе по правовому воспитанию учащихся. ДАХО. Ф-Р 3598. Оп. 3. Спр. 24. 92 арк.

9. Справки и акты об итогах проверки учебно-воспитательной работы и производственой деятельности сельских профтехучилищ. ДАХО. Ф-Р 3598. Оп. 3. Спр. 28. 222 л.

\section{References:}

1. Holovko, N. (2007). Pravova pedahohika [Legal pedagogy]. Kyiv: MAUP [in Ukrainian].

2. Typovi polozhennia pro zahin yunykh dzerzhyntsiv ta pro prophilnyi zahin yunykh druziv militsii [Typical regulations on groups of young Dzerzhynivtsi and the specialized group of friends of militia]. (1978). Zbirnyk nakaziv ta instruktsii Ministerstva Osvity Ukrainskoi RSR, 18, 25-32 [in Ukrainian].

3. Zuibyn, L. (1982). Uchebno - vospitatelnaya rabota s trudnymi uchashchimisya [Teaching and educational work with troubled adolescents]. Moscow: Vysshaya shkola [in Russian].

4. Tereshchenko, H. (1988). KPSS, Sovetskoye gosudarstvo o podgotovke molodoy smeny rabochego klassa 1940-1987 [CPSS, Soviet state on preparation of young working class]. Kyiv: Vysshaya shkola [in Russian].

5. Kuzmiskyi, A., \& Omelianenko, V. (2008). Pedahohika [Pedagogy]. Kyiv: Znannia-Pres [in Ukrainian].

6. Otchet ob ideyno-vospitatelnoy, kulturno-massovoy i phizkulturno-sportivnoy raboty za 1976 [Report on ideological and educational, cultural and recreational, and physical culture and sport work in 1976]. Fund 3598. Inventory 3. File 19. State Archive of Kherson oblast [in Russian].

7. Sayushev, V. (1987). Organizatsiya $i$ sovershenstvovaniye professionalno -tekhnicheskogo obrazovaniya [Organization and improvement of vocational education]. Moscow:Vysshaya shkola [in Russian].

8. Spravki uchilish o rabote po pravovomu vospitaniyu uchashchikhsya [References of specialized schools about work on legal education of pupils]. Fund 3598. Inventory 3. File 24. State Archive of Kherson region, Kherson [in Russian].

9. Spravki i akty ob itogakh proverki uchebno - vospitatelnoy rabotu i proizvodstvennoy deyatelnosti selskikh prophtekhuchilishch [References and acts on results of inspection of teaching and educational work of work activity of rural vocational schools]. Fund 3598. Inventory 3. File 28. State Archive of Kherson region, Kherson [in Russian].

Pyslar A. B., orcid.org/0000-0001-6843-4655

\section{LEGAL EDUCATION OF THE YOUTH IN INSTITUTIONS OF VOCATIONAL EDUCATION IN UKRAINE (THE 70S OF THE XXTH CENTURY)}

In the article it was studied the way of organizing legal education of the youth in the 70s of the XXth century in institutions of vocational education in Ukraine on the basis of sources analysis.

Different forms of legal education the use of which was aimed at performing tasks of legal education such as formation of legal awareness; development of skills and the way of behaving in pupils according to law rules; formation of an active position of pupils in the legal sphere; elimination of wrong views and beliefs in legal awareness of pupils by teaching staff of vocational educational institutions were considered. 
It was stressed that in the 70s of the XXth century in institutions of vocational education in Ukraine with the aim of legal education of the youth lessons in disciplines "Matters of the Soviet Law" and "Labour Law" were held. Also, law universities, recreation clubs, rooms and corners of the Soviet law were created. During out - of - class activities lectures, lecture - rooms, discussion forums, question - and - answer sessions, disputes, law months, conferences on particular topics were organized. The articles from the journal "The Man and the Law" were discussed and wall papers were created. Groups of "Young Dzerzhyntsi", "Courts of Honour", "Community Court", councils of re education and preventative measures operated. Awareness - building work with parents was undertaken. Thus, awareness - building work was beneficial in the process of which all the attention was focused on explanation and persuasion. The formation of legal awareness of youth was predominant while other tasks of legal education were neglected.

It was summarized that without regard for above mentioned in the 70s of the XXth century in institutions of vocational education in Ukraine there was a complex approach to organization of legal education of youth and the work in this direction was done systematically.

Key words: institutions of vocational education, the youth, legal education, tasks of legal education, forms of legal education.

Дата надходження статті: 17.01.2020 p. Рецензент: доктор педагогічних наук, доцент Яиула Т. В.

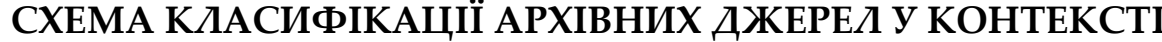 ІСТОРИКО-ПЕДАГОГІЧНИХ ДОС ІІДЕНЬ РОЗВИТКУ ВІТЧИЗНЯНОЇ СИСТЕМИ МОРСЬКОЇ ОСВІТИ В КІНЦІ ХІХ - НА ПОЧАТКУ ХХІ СТОДІТТЯ}

Стаття присвячена особливостям класифікації архівних джерел в історико-педагогічних дослідженнях ьенези вітчизняної системи морської освіти в кінці XIX - на початку XXI столітmя.

Автором констатовано, що розширення архівної джерельної бази з вищезазначеної проблематики вимагае вирімення питання ї̈ класифікації. Водночас установлено, що це питання все ще залишаеться відкритим. Зазначено, що класифікації архівних джерел у сучасних дослідженнях, пов'язаних зі становленням $i$ розвитком системи підготовки фахівців морської галузі, ьрунтуються переважно на територіальному принципі.

За результатами дослідження розроблено комплексну схему класибікацї матеріалів архівних установ, які розкривають јенезу вітчизняної системи морської освіти в кінці ХІХ на початку XXI століття, з урахуванням 8 критерї̈в: форми фіксацї̈ документа (друковані, рукописні, фотодокументи); територіального критерію (документи вітчизняних та іноземних архівів); хронологічного критерію (документи дорадянського, радянського періодів та періоду незалежності); типу власності (документи загальнодержавних архівних установ, архівів закладів освіти морського профілю та приватних архівів); типу фондоутворювача (матеріали фондів органів влади, закладів освіти морського профілю, дотичних організацій, персоналій); рангу документа у вертикальній ієрархіӥ (документи загальнодержавного, локального значення, у межах конкретного закладу морської освіти); фактичної цінності (документи, щео безпосередньо розкривають особливості та закономірності досліджуваного історико-педагогічного явища, розвитку морської галузі

*C Солодовник А. O.

U3 257 